\title{
Converging and diverging stances on target varieties in collateral languages: The ideologies of linguistic variation in Irish and Manx Gaelic
}

\begin{abstract}
This article will argue that language revival movements, particularly those founded in the ethno-nationalist era of the late $19^{\text {th }}$ and early $20^{\text {th }}$ centuries, retain founding overt beliefs rooted in an ideological commitment to a specific language because of its role as the authentic and legitimate cultural vehicle of a distinct people. Revival is thus the reinstatement of cultural distinctiveness based on traditional language. Revivalists have in the past afforded the language varieties of the remaining traditional native speech communities a high prestige status based on their perceived ethnolinguistic authenticity. However, after more than a century of language maintenance and revivalism, significant linguistic institutionalisation, a strong presence in schooling and new socialisation mechanisms outwith the traditional speech communities, some minoritised languages have regained a degree of their sociolinguistic vitality by the advent of 'new speakers' who have no organic relationship with the traditional language community. The ways that these 'new speakers' and 'learners' of previously displaced languages negotiate linguistic authenticity and ethno-cultural legitimacy in our contemporary late modern period provide challenges to established value-laden perceptions about language revitalisation and regeneration of traditional speech communities and the long-held belief in the prestige of 'native' speech as the target variety. This discussion will draw on data from recent fieldwork among contemporary speakers of Irish and Manx Gaelic in order to analyse both their overt and more hidden beliefs about the utility and legitimacy of traditional and revival speech. It will further argue that 'traditional' and 'new' speakers do not live parallel sociolinguistic realities in which they are sociolinguistically isolated from one another, but rather that contemporary speakers contest the prestige of both traditional and innovative revival varieties in their language practices and ideologies in a multi-faceted fashion.
\end{abstract}

Keywords: Language ideology, folk linguistics, linguistic variation, Irish, Manx Gaelic

\section{Introduction}

\section{Iconisation, erasure and fractal recursivity}

The standards for what counts as legitimate, acceptable and authentic language usage are commonly established and perpetuated by powerful societal institutions or individuals who assume responsibility, or are assigned responsibility through consensus, for identifying target language varieties (Lippi-Green 2012). Folk linguistic approaches also hold that the folk also contribute to the establishment and maintenance of ideologies on correct, appropriate and authentic language usage through grassroots prescriptivism which can correspond to official models to a greater or lesser extent (Niedzielski and Preston 2003), even though these overt ideologies on variation are not necessarily borne out in speech practices. The folk are aware of the linguistic variation that exists in languages they use, including the traditional and post- 
traditional variation attested in minoritised languages. The folk ascribe values and meanings to alternative ways of using language based on existing ideological regimes and, accordingly, inherently believe some varieties to be correct and acceptable and others varieties to be incorrect and unacceptable. While the erosion of prescriptivism in language has been identified as a possible result of sociolinguistic changes associated with late modernity (Coupland 2007; Coupland and Kristiansen 2011), the technologisation and mediatisation of society arguably also affords social actors more opportunities to engage with variation and provides more forums to voice their grassroots prescriptivism (Heyd 2014). This contributes to the maintenance of the ideological construct of standard languages and language standards thereby ensuring that speakers constantly and reflexively engage with linguistic variation at an ideological level.

The social meaning of linguistic variation, as expounded by social actors, is well established as an area of enquiry for sociolinguists, as well as for researchers in other, related fields. Ideologies around language variation evince speakers' engagement with the sociolinguistic environments in which they function and subsequently allow speakers to actively align themselves with myriad groups and individuals through shared practices and ideologies. It is thus posited that folk linguistic perceptions of the linguistic variation encountered by speakers can reveal the dynamic identificational and reactional forces at work within sociolinguistic communities as speakers (re)negotiate their identity in relation to their own communities of practice and to those of sociolinguistic others (Garrett 2005, 2010). A common thread in speakers' subjective responses to linguistic variation in minoritised languages has been the prevalence of ideological claims of legitimacy, authenticity and language ownership (Walsh and O'Rourke 2015). These claims are often interwoven with the essentialist indexical links commonly existing between language variation and the sociocultural attributes of speakers. The advent of post-traditional, habitual new users of Irish and Manx Gaelic, as well as other minority languages, alters the composition of the speech community and prompts users of the languages to evaluate the traditional and post-traditional language features, styles and practices of contemporary speech. The manner in which social actors engage with the diversification of language practices that has resulted from the advent of new speakers of Irish and Manx can be analysed within Gal and Irvine's (Gal and Irvine 1995; Irvine and Gal 2009) taxonomy of language ideological process which includes the related semiotic processes of iconisation, erasure and fractal recursivity. 
Iconisation of course involves the transformation of the sign relationship between linguistic features and the social images with which they are linked. In this way, linguistic features become iconic of speaker identities. In terms of the data presented here, participants at least recognise and sometimes reproduce and subscribe to traditional ideologies around variation in revival languages that centre on the perceived ethnolinguistic authenticity and legitimacy of traditional speech and therefore dichotomise traditional and post-traditional speech varieties and communities.

Erasure revolves around ignoring, not attending to or explaining away facts that are inconsistent with the ideological scheme. The iconisation of traditional and posttraditional speech in Irish and in Manx requires the erasure of the internal social and linguistic differences that comprise each group. This results in the blurring of the social and linguistic boundaries between traditional and post-traditional communities.

Fractal recursivity refers to the process whereby the differences that are made to be iconic are used in the creation of the sociolinguistic other. At the same time, the same oppositions that are used to distinguish between groups are also found within groups so that solidarity and dissonance can exist simultaneously within groups.

\section{Traditional and post-traditional variation in contemporary Irish}

Contemporary spoken Irish incorporates both traditional and post-traditional speech varieties. The historical dialectal differences that became increasingly documented from the Early Modern period of the language led to the emergence of what are generally categorised as three main regional varieties of spoken Irish - Ulster Irish in the north, Connacht Irish in the west and Munster Irish in the south. Today, the three main traditional spoken dialects of the remaining Irish-speaking, bilingual communities of the Gaeltacht, as well as the various local dialects within each of these regional varieties, are practised in their conservative forms mainly by speakers born before the 1960s (e.g. Ó Curnáin 2007).

Within the broader context of an ongoing shift from Irish to English as main vernacular in the Gaeltacht communities, younger Gaeltacht speakers increasingly diverge from the traditional linguistic practices of older speakers (Ó Curnáin 2007; Ó Sé 2000; Nic Fhlannchadha and Hickey forthcoming; Péterváry et al. 2014). Although younger Gaeltacht speakers of Irish are a linguistically heterogeneous cohort displaying features, styles and practices that range from the traditional to the post-traditional, innovation is generally attested 
in all aspects of the language use of younger speakers. Post-traditional variation in Gaeltacht youth speech is evident in phonology, syntax and verbal structures, for instance, while younger speakers also frequently engage in translanguaging and display semantic transference from English structures.

These changes can be attributed to the late modern sociolinguistic reality of the Gaeltacht. For young Gaeltacht speakers, access to traditional speaker models is often limited due to the fragmentation of the extended family and the diversification of the labour market (Ó hIfearnáin 2008). Furthermore, the institutionalisation of the Irish language since the foundation of the state in the 1920s perhaps also triggered a lasting culture of outsourcing some, or indeed all, of the responsibility for the cultivation of Irish from the family and the community to the state, and especially to education. For some, the development of proficiency in English through the use of that language in the home and in the community may have become part of a folk linguistic strategy to achieve skilled bilingualism in Irish and English among children thereby again reducing access to traditional speaker models (Ó hIfearnáin 2006, 2013). The proliferation of communication technologies and digital media, meanwhile, facilitates the resultant expansion of Irish into new domains. With the physical and virtual mobility that characterises late modernity come opportunities to interact with diverse users of Irish. Combined, the above factors reduce opportunities for engagement with the traditional vernacular and instead provide myriad opportunities for engagement with non-local traditional varieties of Irish, with post-traditional Gaeltacht speech, with post-Gaeltacht speech and with the standard written norm, all in the context of community language attrition and shift to English (Ó Murchadha 2015). This reality is reflected in modern Gaeltacht youth speech.

Similar to the Manx Gaelic context, the post-Gaeltacht in Ireland represents a situation of what Ó hIfearnáin (2015) refers to as language revival after extreme or complete language shift. While Irish was once the community language of all of the island of Ireland, the language ceased to be the community language in what is now the post-Gaeltacht following an historical language shift from Irish to English as main vernacular. Passive and active users of Irish are, however, found dispersed throughout the post-Gaeltacht. This is sometimes due to migration from traditional Gaeltacht communities, but it is more commonly due to new speakers initially developing proficiency in Irish through the education system where they encounter Irish as a compulsory subject in English-medium schools or as a medium of instruction in immersion pre-primary, primary and post-primary schools.

As the link with the traditional local vernacular once spoken in the post-Gaeltacht has been broken there is no existing prestige local spoken target variety for these habitual new 
speakers of Irish in the post-Gaeltacht. Additionally, no widely accepted standard spoken norm for Irish exists as a target variety for new speakers (Ó Murchadha 2015). Traditionally, users of Irish in the post-Gaeltacht have filled this linguistic lacuna by aligning their spoken practices with a particular traditional Gaeltacht dialect as a target variety, though few speakers achieve complete fluency in such a local vernacular (Ó Dochartaigh 2000). Post-traditional variation sometimes emerges as speakers seek to replicate the target variety. The linguistic alignment with the Gaeltacht has its roots in the prestige accorded traditional speech and is often due to either personal affiliation with that dialect or through experience of that variety through schooling. While many contemporary speakers still align themselves with their local Gaeltacht vernacular, approximation to the traditional speech variety has become somewhat problematic. This is due in the first instance to pragmatic issues. Access to traditional speaker models may be limited owing to traditional Gaeltacht speakers of Irish becoming rarer while at the same time the opportunities to access alternative linguistic models are abundant as a result of education and communication with diverse speakers of Irish through personal encounters or through digital and broadcast media.

The pragmatic issue of access to linguistic models is closely related to the ideological issues around the identification of authentic and legitimate target varieties for spoken Irish. Continued approximation to the traditional Gaeltacht vernacular as a target variety, if not explicitly challenged, is at least implicitly questioned in patterns of language usage in the postGaeltacht (Mac Mathúna 2008). It is by now generally acknowledged that a post-Gaeltacht new speaker variety of Irish has emerged that is perceived to operate independently of traditional Gaeltacht speaker norms. Post-traditional new speakers of Irish transgress traditional linguistic practices of the Gaeltacht vernacular in all aspects of language use (Maguire 1991; Ó Duibhir 2009; Ó hIfearnáin and Ó Murchadha 2011), just as their post-traditional Gaeltacht counterparts do.

Post-traditional variation doesn't represent a mere linguistic failure on the part of posttraditional speakers of Irish to replicate the mooted prestige traditional Gaeltacht varieties in their own practices. The diffusion of post-traditional linguistic innovation is a means through which post-traditional speakers in the Gaeltacht and in the post-Gaeltacht negotiate their sociolinguistic environments and locate themselves within their respective peer networks and broader social networks. The proliferation of this variation is attributable to pragmatic factors related to levels of access to traditional and post-traditional speaker models as well as to the speakers' ideological stances. This is an agentive identificational response by post-traditional speakers to the changing dynamics of the Irish language in the late modern age where non- 
traditional social and linguistic practices are becoming synonymous with one another. It is the communicative and social functionality of post-traditional speech varieties, Gaeltacht youth speech and post-Gaeltacht speech alike, that sustains them. The emergence of post-traditional varieties and variation in Irish is a challenge to the traditional conceptualisations of authentic, legitimate and acceptable language usage that will now be discussed.

\section{The valorisation and stigmatisation of linguistic variation in revitalisation and revival}

The model of language valorisation that has dominated the ideological landscape of Irish since the end of the nineteenth century is a microcosm of broader patterns of valorisation in minoritised languages more generally. Revival and maintenance efforts have thus focussed on the reinstatement of cultural distinctiveness based on traditional language. Revivalists consequently afforded the language varieties of the remaining traditional native speech communities a high prestige status based on their perceived ethnolinguistic authenticity. This ideological scheme has been expounded in terms of the zeitgeist that prevailed at the turn of the twentieth century, characterised by the proliferation of Romanticism, in its scholarly and political guises alike (Ó Conchubhair 2009), by the burgeoning of realism as a literary technique (Titley 1991) and by the influence of Darwinism on philology and on the social sciences more generally (Ó Conchubhair 2009).

These factors combined fostered an enduring and intrinsic folk belief in the authority, the legitimacy and the authenticity of traditional Gaeltacht speech. This folk linguistic ideology on language variation still permeates the public psyche. Post-traditional linguistic features of Gaeltacht youth speech and of post-Gaeltacht speech are commonly perceived, in Niedzielski's and Preston's (2003: 22) terms, as performance deviations from competence and not as alternative competencies. The conditions of late capitalism and late modernity have, however, been described as resulting in "an as yet unresolved destabilization of hitherto hegemonic discourses linking languages to cultures, identities, nations and States" (Heller, Pujolar and Duchêne 2014). Given the sociolinguistic reality of late modern spoken Irish where posttraditional variation continues to diffuse, it is germane to consider the efficacy of a linguistic model that prescribes continued alignment with traditional Gaeltacht speech models and to assess the robustness of the ideologies that support this paradigm. It is in this context that the evidence from Manx Gaelic becomes particularly useful because the language exists entirely among post-Gaeltacht speakers, the last traditional speech communities having almost ceased to use Manx by the start of the Gaelic revival in the nineteenth century, the last reputed traditional native speaker having died in 1974. 


\section{Data Collection}

The data for this paper are based on folk linguistic interviews with speakers of Irish and Manx Gaelic. The data on Irish were collected in 2010 as part of a larger project on subjective responses to traditional and post-traditional variation in modern Irish. 23 focus group interviews were conducted in Gaeltacht secondary schools in the southern province of Munster with 80 Gaeltacht teenagers aged between 15-19 years of age. These students had previously completed a speaker evaluation experiment as part of the same project. Additionally a pilot interview was conducted with a teenaged post-Gaeltacht speaker as a point of comparison and as a precursor for a future study. The Manx discussion draws on qualitative fieldwork and a sociolinguistic survey conducted in the Isle of Man in the autumn/winter of 2013-2014 among 110 speakers and adult learners of Manx Gaelic. All the participants were either attending classes for learners or gatherings at social occasions in the evening or at lunch times specifically designed for more fluent speakers. About 30 of the participants were very fluent speakers while the others had a diverse range of abilities in the language and exposure to contemporary usage and the many recordings of traditional speakers and body of more traditional written texts.

\section{Evidence}

When considering the data from the teenaged Gaeltacht speakers, it's worth noting again that although these participants are based in the Gaeltacht, Gaeltacht youth speech encompasses a broad spectrum of linguistic features and practices. Even the participants from the most traditional of backgrounds can be placed on the threshold between traditional and new speaker categories. This is owing to the dramatically different sociolinguistic environments in which they have been raised and the resultant proliferation of post-traditional linguistic variation among younger speakers in these bilingual communities, as already discussed. Nevertheless, the teenaged Gaeltacht participants predictably recognise, reproduce and subscribe to dominant language ideologies around variation in Irish and in revival languages more broadly. The intrinsic belief in the inherent correctness, authenticity and legitimacy of the traditional local vernacular becomes evident in the responses of Gaeltacht teenagers.

\section{Extract 1}

Ciarán: Thá sí [an chanúint áitiúil] deas alright. Is deas rud difriúil a bheith agat ó gach éinne eile. Is dócha go bhfuil sí difriúil ó gach éinne eile agus gur féidir leat bród a bheith agat as $\sin$. 
[It [the local dialect] is nice alright. It's nice to have something different from everybody else. I suppose it's different from everybody else and you can be proud of that.]

\section{Extract 2}

Máire: Tá sé tábhachtach do Ghaelainn féin a chleachtadh, mar a dúirt na lads, tá stair ag baint léi.

[It's important to practice your own Irish, as the lads said, it's rooted in history.]

\section{Extract 3}

Áine: Thá sí [an urlabhra áitiúil] níos saibhre agus níos nádúrtha, is dóigh liom.

[It [the local vernacular] is richer and more natural, I think]

\section{Extract 4}

Oisín: Just tá blas acu [na cainteoirí áitiúla] agus tá na focail go léir acu.

[They [the local speakers] just have the right sounds and all the words.]

The overt ideology revealed by participants is rooted in dominant language ideologies around variation in spoken Irish and in local patriotism and subsequent allegiance to the local vernacular. The prestige of traditional local speech practices are still firmly established in the overt ideologies on acceptable target varieties for Irish revealed by participants in the folk linguistic interviews. This is despite the quite dramatic changes in the linguistic practices of Gaeltacht Irish speakers locally and nationally since the middle of the last century. Further to the local patriotism displayed by participants, however, a pluricentric pattern of valorisation for the traditional dialects is revealed in participants' acknowledgement of the parallel mastery of traditional dialectal speakers in other, non-contiguous Gaeltacht areas. The perceived legitimacy of traditional speech as a target variety is clear in participants' metalinguistic talk about language no matter the traditional Gaeltacht dialect.

\section{Extract 5}

Tadhg: Bhuel, mar a dúirt mé, níl mórán suime agam í a labhairt, ach you know tá sé tábhachtach i gcomhair na lads ón áit sin.

[Well, as I said, I don't have much interest in speaking it, but you know it's important for the lads from that place.] 
Participants posit that dialectal difference is an important feature of the traditional Irish vernacular and that this illustrates that Irish is just like other functional modern languages.

\section{Extract 6}

Fianait: Tá sé go maith samplaí difriúla a bheith ann den nGaelainn. Sin is dóigh liomsa, pé scéal é.

[It's good that there are different examples of Irish. That's what I think, anyway.]

\section{Extract 7}

NÓM: I gceantair eile, dá mbeifeá i gceantar eile Gaeltachta, cad a dhéarfá leis na daoine sin, daoine óga?

Eibhlís: Dhéarfainn leo an chanúint a choimeád mar táimid ag rá gur fuath linn an chanúint seo, an chanúint súd, ach is dóigh liom go bhfuil sé ana thábhachtach dúinn go mbíonn grúpaí difriúla sa teanga Ghaelainne, mar atá in aon teanga.

[NÓM: In other areas, if you were in another Gaeltacht area, what would you say to those people, young people?

Eibhlís: I'd tell them to keep their own dialect because we're saying we hate this dialect and that dialect, but I think it's very important to have different groups in the Irish language, just as in any language.]

While the dialectal differences that comprise traditional Gaeltacht speech are acknowledged by the teenagers, those differences are subsequently erased as traditional Gaeltacht speech and speakers are homogenised as a distinct and coherent social, cultural and linguistic entity through their identification as alternative target varieties for spoken Irish. Participants' ideologies are illustrative of an imagined solidarity across Gaeltacht areas despite the social and linguistic dissonance that exists across and within Gaeltacht areas. The unification of diverse Gaeltacht speech practices allows social actors to place these practices in direct opposition to the post-traditional practices of post-Gaeltacht speakers that are perceived as sociolinguistically alien. Therefore, despite the egalitarian, pluralist ideology that is evident in the iconisation of traditional speech, this polynomic model of linguistic valorisation does not extend to incorporate post-traditional speech varieties that are proliferating among new speakers in the post-Gaeltacht. The utility of post-Gaeltacht speech is not contested, but it is 
iconised as an inauthentic, synthetic variety. Participants point to traditional models of language revival in which new speakers draw on the well of traditional communities to develop the right type of language proficiency. They propose this as the beau ideal for new speakers. In contrast to the prestige status attributed to the Gaeltacht dialects, post-Gaeltacht speech is indexed as an inauthentic variety to be avoided for fear of ridicule.

\section{Extract 8}

Cian: Aam, tá siad ag labhairt Gaelainne so tá sé sin go maith, ach ní maith liom í really. [Aam, they're speaking Irish so that's good, but I don't like it really.]

\section{Extract 9}

Saoirse: Níl aon bhlas acu. Níl sí nádúrtha. Níl siad in ann í a labhairt go nádúrtha.

[They don't have the right sounds. It's not natural. They're not able to speak it naturally.]

\section{Extract 10}

Cormac: Nach mór go ndéarfainn gur fuath liom an saghas san Gaelainne.

[I'd nearly go so far as to say that I hate that type of Irish.]

\section{Extract 11}

Séamas: Dá mbeadh an Ghaelainn san agat, bheadh daoine ag rá nach Gaelainn cheart í agus gur cheart dul dtín nGaeltacht ar feadh tamaill agus an Ghaelainn cheart a fhoghlaim sa tslí sin.

[If you had that sort of Irish, people would say it wasn't proper Irish and that you should go to the Gaeltacht for a while and learn proper Irish that way]

\section{Extract 12}

Ciarán: Ach chaithfidís 'bheith ag cónaí anseo i measc na ndaoine ar feadh trí mhí, sé mhí, le bheith á labhairt i gceart, ní thuas i mBaile Átha Cliath i rang oíche éigint le múinteoir nach mbeadh aon scil cheart acu. Sin an tslí go gcaithfidh siad é a dhéanamh; maireachtaint timpeall ar feadh tamaill i measc na ndaoine Gaeltachta agus ansan gheobhaidh siad i gceart é.

[But they'd have to live here amongst the people for three months, six months, to speak it properly, not in Dublin in some night class with a teacher without any proper skill. 
That's the way they will have to do it; live among the Gaeltacht people for a while and then they'll get it right.]

Overt traditional ideologies on variation in spoken Irish are evidently an enduring, dominant presence in folk linguistic talk about Gaeltacht and post-Gaeltacht speech practices. Ideologising the Gaeltacht as the authentic source of legitimate linguistic practice in Irish facilitates the erasure of the post-traditional variation practised by the participants and by their Gaeltacht peers, even though the very presence of this variation implicitly challenges traditional ideologies on variation in Irish (Ó Murchadha 2013). This paradox is illustrative of familiar schisms between overt and covert stances on linguistic variation (e.g. Labov 2001). But, is also indicative of destabilising discourses and linguistic ideologies under the conditions of late capitalism (described by Heller et al. 2014) and in what can be described as a period of language activism that is characterised by both language maintenance and revival (Ó hIfearnáin 2014). Despite the robustness of traditional ideologies in open responses to variation, younger Gaeltacht speakers simultaneously create fractals within the traditional Gaeltacht communities as they distinguish themselves socially and linguistically from more traditional speakers through their post-traditional linguistic practices. They implicitly challenge the status of traditional Gaeltacht speech varieties as the only legitimate ways of using the language. Stances of solidarity and dissonance thus coexist within Gaeltacht areas as the iconisation of the Gaeltacht revealed in overt ideologies is implicitly challenged by the covert ideologies on variation expressed through the speech practices of young Gaeltacht speakers that indicate the presence of fractals within the Gaeltacht.

Contemporary speakers of Manx Gaelic also struggle with questions of legitimacy about the form of language that they speak and its relationship with the speech of the last traditional native speakers. Although for Manx speakers, the traditional speech is indeed something of the past, it is still iconised, if ambiguously, and is readily available to learners in sound recordings. Many of the participants in the project also pointed to some of the older generation of revival speakers as those who learnt their language while the traditional speakers were still alive and who consequently conserve some distinctively traditionalist pronunciations. Many fluent speakers of Manx are characterised by a strong metalinguistic awareness about the language that they speak and overtly reflect on the issue of target variety. One fluent speaker exemplifies this, wondering whether the traditional or revival speakers are 'better' or whether she should try to glean more authenticity by reference to Irish and Scottish Gaelic: 


\section{Extract 13}

Cha nel mee shickyr cre'n "sampleyr share" my ta'n lheid ayn. Vel eh ny share loayrt rere adsyn dynsee y çhengey? Rere y veggan loayr ee tra v'ee caghlaa dy tappee trooid laccal loayreyderyn, as cummaght hrome Baarle urree? Ny shirrey "blass tradishoonagh" ass scrutaghey çhengaghyn Gaelgey elley son red ennagh "smoo Gaelgagh"?

[I am not sure who/what is the best example, if such a thing exits. Is it better to speak like those who have learnt the language? Like the few who spoke it during the time that it was being rapidly lost for want of speakers, with heavy Anglicisation? Seeking to have more of a 'traditional accent' and analyse the other Gaelic languages for something 'more Gaelic'?]

Other of the most fluent speakers are more specific about what they believe to be the 'best' way to speak the language, and juxtapose what they see as a more traditional speech with the speech of some of the new fluent speakers, specifically some who have learnt the language at school.

\section{Extract 14}

Foddee oo toiggal ny t'ad gra ga mannagh vel blass glen oc, agh cha nel mee son snaue ersooyl jeh'n çhenn vlass.

[You can understand what they [new speakers] are saying despite not having a clear accent, but I am not in favour of getting rid of the old accent]

Despite the speaker's stance in favour of the traditional speech variety, he is also quite conciliatory to the variety spoken by his younger counterparts. The inner conflict, seen so clearly in the stance of the young Irish Gaeltacht informants as they negotiate between justifying the authenticity and validity of their own speech variety in the context of the local variety spoken by their elders, is clearly evident in the Manx setting. Older and more fluent speakers generally espouse what they perceive to be a traditional or traditionalist variety, based not just on the pronunciation of the late-nineteenth and twentieth century traditional speakers, but also on earlier forms of the language based on written sources which they see as more consistent. However, not all learners and emerging new speakers do engage in this negotiation in time and space with the traditional language as a target variety. This is particularly articulated 
with reference to the Manx accent. The Gaelic word for 'accent' (blas in Irish, blass in Manx) also corresponds to 'taste' or 'flavour', and in a stance that reflects the erasure of authenticity and the fractal recursivity demonstrated in the Irish examples, some Manx learners in our data reject the traditional speech as not being authentically related to the present reality of the Isle of Man. Revived speech is constructed as a language that could or should reflect this social reality rather the Gaelic culture of the past.

\section{Extract 15}

Manx induces the speaker to use a certain accent that is quaint but sounds artificial. It is not unpleasant and even at times seductive but it possibly needs to evolve into something more relaxed, modern and conversationally more benign. I do not want to stifle individuality but rather promote broader acceptability.

\section{Extract 16}

Some accents [recordings of traditional speakers] are too thick for beginners to follow though a real pleasure to listen to. I enjoy occasionally listening to tapes of old Natural Manx Speakers (e.g. Ned Maddrell) in museums etc. (and on YouTube).

These informants also hedge their comments with accommodative words about those who might disagree, a trait which we saw in the more established, fluent speakers, and perhaps one which is not uncommon in very small revival speech communities where it is felt that all efforts to learn and speak have merit.

A folk linguistic interpretation of language change which uses 'accent' as its axis is, however, expressed by many speakers and learners of Manx. The argument is that Manx English has changed hugely in its form over the last century or more as the country's population turned increasingly more towards England for social and economic interaction with less and less isolation and/or contact with Ireland and Scotland. There has also been very heavy immigration to the Isle of Man, mainly from England, since the establishment first of the tourism industry and then the modern financial services sector. As a result, by 2011 (Isle of Man Government 2012) only $48.1 \%$ of the population of 84,497 was born in the country, and of course many of those born there may have no Manx or only some Manx heritage. The stance of these informants is that as the English spoken in the Isle of Man has become increasingly like that spoken in north western England, so Manx Gaelic would have also changed if it had continued 
to be the main language of the population. Modern spoken Manx, as the language of the Isle of Man rather than as the linguistic expression of the traditional Gaelic culture of the Isle of Man in a modern form, might justifiably reflect the accent of the English spoken by the current population as much as a revived Gaelic speech of the past, possibly more so.

\section{Extract 17}

I like listening to the recordings as I like their stories and the way they speak reminds me of my older relatives who have now passed. Their accent and way of speaking was of their time and that time has now passed too. Even if Manx had remained the main language we would not be speaking how they spoke anyway as the language would have changed....a sign of being a living language. If we spoke exactly the same it would be like saying we have not moved on or developed and that Manx is an inorganic dead language.

\section{Extract 18}

It's important to approximate how words should be pronounced but, realistically, what is a Manx accent these days? People Manx born have accents with a variety of influences, depending on where their family are from - Liverpool, Manchester, Lancashire, Scotland, Ireland and, more commonly now, much further afield. More and more I meet Manx speakers who are from countries further afield. Manx is at least their third language, so I think it's unrealistic to expect them to speak the language with an 'authentic' accent, whatever that is!

These ideological contestations were typical of many of the learners and emerging speakers, and possibly reflect wider beliefs in Manx society and also in Ireland among those who do not yet speak the language fluently or who have little contact with the posited traditional varieties. Although the Manx research revealed that the more fluent speakers do have much more awareness of the fundamental question of what variety of language was being revived or recreated, the very emergence of a cohort of fluent, literate, active speakers creates a new set of linguistic practices which are accorded the prestige status by learners that might previously have been occupied by traditional speakers. As one fluent speaker says;

\section{Extract 19}

I regard Doug Fargher, Dick Radcliffe \& Brian Stowell [prominent revival speakers] as my Manx Gods. 
From the perspective of the most fluent speakers themselves, several of those in this project recognise that although they are now in a position to be able to appreciate the recordings of the traditional native speakers for their linguistic value, their stance is already defined by their participation in an established group of speakers with their own values.

\section{Extract 20}

Ren mee geaistagh rish ny recortsyn voish Skeealyn Vannin tra ren mee goaill toshiaght ec gynsagh gaelg agh ec y tra t'ayn cha nel mee jannoo monney gynsagh lhimmed jeh ayns co-loartys. Ta fys aym dy beeagh eh ny smoo cooie dou nish na roie!

[I used to listen to the Irish Folklore recordings Commission [1948 recordings of native speakers now digitally remastered] when I started learning Manx but nowadays I don't do much learning beyond conversation. I know that it would be more useful/appropriate for me now than it was before!]

Likewise, the post-traditional practices of post-Gaeltacht new speakers of Irish implicitly challenge the legitimacy, the authenticity and the prestige of the traditional vernacular. The data from the pilot interview with Muiris, a post-traditional post-Gaeltacht speaker, however, also reveals the existence of a more overt questioning of the status of traditional Gaeltacht speech. Muiris can be described as linguistically quite typical of a highly proficient postGaeltacht speaker who does not overtly identify with a traditional Gaeltacht dialect. While Muiris recognises the overt prestige of traditional speech varieties, he openly challenges this ideology. Through his own speech practices, but also through his overt ideology, Muiris iconises post-Gaeltacht speech not only as a functional variety but also as a legitimate speech variety. Again, this stance places post-Gaeltacht speech in opposition to Gaeltacht linguistic practices. Again, this results in the dichotomisation of traditional and post-traditional practices and speakers.

\section{Extract 21}

Muiris: Amanta anseo cuirtear cineál sprioc os ár gcomhair go mbeadh sé mar phríomhchuspóir agus aidhm againn teacht amach le céim agus a bheith in ann dul síos go dtí Gaeltacht áit éigin agus nach n-aithneoidís nach as an áit sin duit. Níl sé sin mar sprioc agam riamh. Níl sé mar sprioc in aon chultúr eile san Iarthar go labhraíonn tú ar 
nós gur duine tuaithe tú ionas ardchaighdeán teanga a bheith agat. Sin i ndáiríre atá á rá.

[We're sometimes presented here with a sort of target that our main objective and aim should be to gain a degree and be able to go to some Gaeltacht area and that they would not be able to recognise you as not being from that area. That's never my aim. It's not the aim in any other culture in the West that you ought to speak like a rural person in order for you to speak the prestige language variety. That's essentially what is proposed.]

The harmony between Muiris's overt and covert ideology is striking for its atypicality. Allied with the covert ideologies that can be implied from the proliferation of post-traditional practices in the Gaeltacht, they speak to something of a displacement of traditional Gaeltacht speech as the only legitimate and acceptable way to use Irish. Although this ideological displacement has not permeated the overt ideologies of the Gaeltacht teenagers interviewed, it is symptomatic of the ongoing destabilisation of hegemonic discourses and ideologies in contemporary society.

\section{Conclusion}

The emerging re-evaluation of ways of using language indicates that we are potentially moving towards a more widespread, overt re-ideologisation of the linguistic variation that constitutes late modern spoken Irish. This process has also been underway in the Isle of Man since the start of the revival period but has become more salient as the language has become more institutionalised and opportunities for school pupils and adults to learn it more readily available. The sustainability of conventional linguistic ideologies that valorise traditional varieties remains uncertain in this context. Despite the durability of traditional stances on variation in the overt ideologies of the Gaeltacht teenagers interviewed and in the overt views of the most fluent Manx speakers, we are potentially experiencing what Fairclough (1992: 201) has identified as processes of destandardisation/democratisation. Destandardisation is characterised by a value levelling that results in changes to valorisation models to include varieties not formerly accepted as legitimate, correct and authentic. Alternatively, the destabilisation of conventional ideologies and the ongoing re-ideologisation of minority language speech practices in late modernity may be a feature of demotisation processes. Although language hierarchies and concepts of 'best' language varieties remain intact within demotisation, the valorization of ways of speaking changes so that new varieties become 
recognised as the new legitimate, authentic and acceptable ways of using language (Coupland and Kristiansen 2011). Whatever the result, destandardisation or demotisation, it is becoming clear that what counts as legitimate language usage is being recalibrated and reconceptualised as new patterns of linguistic variation emerge within the contours of late modernity and late capitalism and in the context of minority language activism that focuses on both maintenance and revival efforts.

\section{References}

Coupland, Nikolas. 2007. Style: Language Variation and Identity. Cambridge: Cambridge University Press.

Coupland, Nikolas and Kristiansen, Tore. 2011. "Critical perspectives on language (de)standardisation." In Standard Languages and Language Standards in a Changing Europe edited by Kristiansen, Tore and Coupland, Nikolas: 11-38., Oslo: Novus.

Gal, Susan \& Irvine, Judith T. 1995. "The Boundaries of Languages and Disciplines: How Ideologies Construct Difference." Social Research 62 (4): 967-1001.

Garrett, Peter. 2005. “Attitude Measurement.” In Sociolinguistucs: An International Handbook of the Science of Language and Society edited by Ulrich Ammon, 1251-1260. Amsterdam: Walter de Gruyter.

Garrett, Peter. 2010. Attitudes to Language. Cambridge: Cambridge University Press.

Heller, Monica, Pujolar, Joan and Duchêne, Alexandre. 2014. "Linguistic Commodification in Tourism.” Journal of Sociolinguistics 18 (4): 539-566. doi: 10.1111/josl.12082.

Heyd, T. 2014. "Folk-linguistic Landscapes: The Visual Semiotics of Digital Enregisterment." Language in Society 43 (5): 489-514. doi: 10.1017/S0047404514000530.

Irvine, Judith T. and Gal, Susan. 2009. "Language Ideology and Linguistic Differentiation.” In The New Sociolinguistics Reader edited by Nikolas Coupland and Adam Jaworski, 374377. London: Palgrave Macmillan.

Isle of Man Government. 2012. Isle of Man Census Report 2011. Douglas, Isle of Man: Economic Affairs Division, Isle of Man Government Treasury. Labov, William. 2001. Principles of Linguistic Change: Social factors. Oxford: Blackwell. Lippi-Green, R. (2012) English with an Accent, London: Routledge.

Niedzielski, Nancy and Preston, Dennis R. 2003. Folk Linguistics. Berlin: Mouton de Gruyter. Mac Mathúna, Liam. 2008. "Linguistic Change and Standardization." In A New View of the Irish Language edited by Caoilfhionn Nic Pháidín and Seán Ó Cearnaigh, 76-92. Dublin: Cois Life. 
Maguire, Gabrielle. 1991. Our Own Language: An Irish Initiative. Clevedon: Multilingual Matters.

Ó Curnáin, Brian. 2007 The Irish of Iorras Aithneach, Co Galway. Dublin: Dublin Institute for Advances Studies.

Ó Conchubhair, Brian. 2009. Fin de Siècle na Gaeilge [Fin de Siècle of Irish]. Indreabhán: An Clóchomhar.

Ó Dochartaigh, Cathair. 2000. "Irish.” In Languages in Britain and Ireland edited by Price, Glanville: 6-36. Oxford: Blackwell.

Ó Duibhir, Pádraig. 2009. The Spoken Irish of Sixth-Class Pupils in Irish Immersion Schools, $\mathrm{PhD}$ dissertation, University of Dublin [available online] available at: http://www.spd.dcu.ie/main/academic/education/courses/documents/Taighde_POD.pd $\mathrm{f}$

Ó hIfearnáin, Tadhg. 2006. Beartas Teanga [Language Policy]. Dublin: Coiscéim.

Ó hIfearnáin, Tadhg. 2008. "Endangering Language Vitality Through Institutional Development." In Sustaining Linguistic Diversity: Endangered and Minority Languages and Language Varieties edited by King, Kendall A., Schilling-Estes, Natalie., Fogle, Lyn., Lou, Jia Jackie and Soukup, Barbara: 113-128. Washington: Georgetown University Press.

Ó hIfearnáin, Tadhg. 2013. "Family language policy, first language Irish speaker attitudes and community-based response to language shift". Journal of Multilingual And Multicultural Development, 34: 348-365. doi: 10.1080/01434632.2013.794809.

Ó hIfearnáin, Tadhg. 2014. "Paradoxes of engagement with Irish language community management, practice and ideology." In Peter K. Austin and Julia Sallabank (eds). Endangered Languages. Beliefs and ideologies in language documentation and revitalization. Oxford: Oxford University Press, 29-51.

Ó hIfearnáin, Tadhg. 2015. "Sociolinguistic vitality of Manx after extreme language shift: authenticity without traditional native speakers". International Journal of the Sociology of Language, 231: 45-62. doi: 10.1515/ijsl-2014-0031.

Ó hIfearnáin, Tadhg and Ó Murchadha, Noel P. 2011. "The Perception of Standard Irish as a Prestige Target Variety." In Standard Languages and Language Standards in a Changing Europe edited by Kristiansen, Tore and Coupland, Nikolas: 97-104., Oslo: Novus. 
Ó Murchadha, Noel P. 2013. “Authority and Innovation in Language Variation: Teenagers' Perceptions of Variation in Spoken Irish." In Language (De)standardisation in Late Modern Europe: Experimental Studies edited by Kristiansen, Tore and Grondelaers, Stefan. Oslo: Novus.

Ó Murchadha, Noel P. 2015. "The efficacy of unitary and polynomic models of codification in minority language contexts: Ideological, pragmatic and pedagogical issues in the codification of Irish." Journal of Multilingual and Multicultural Development. doi: 10.1080/01434632.2015.1053811.

O’Rourke, Bernadette and Walsh, John. 2015. "New Speakers of Irish: Shifting Boundaries Across Time and Space." International Journal for the Sociology of Language. 231: 63 - 83. doi: 10.1515/ijsl-2014-0032.

Ó Sé, Diarmuid. 2000. Gaeilge Chorca Dhuibhne. Dublin: Institiúid Teangeolaíochta Éireann. Péterváry, T., Ó Curnáin, B., Ó Giollagáin, C. and Sheahan, J. 2014. Iniúchadh ar an gCumas Dátheangach / Analysis of Bilingual Competence. Dublin: An Chomhairle um Oideachas Gaeltachta agus Gaelscolaíochta.

Titley, Alan. 1991. An túrscéal Gaeilge [The Short Story in Irish]. Dublin: An Clóchomhar. 